\title{
Investment and Financing Policies of Nepalese Enterprises
}

\author{
Kapil Deb Subedi ${ }^{1}$
}

\begin{abstract}
Firm financing and investment policies are central to the study of corporate finance. In imperfect capital market, financing and investment policies of enterprises are dependent to each other. Firm's investment decisions depend upon the access and availability of finance in capital market. But various capital market frictions like information and incentives wedge the efficient allocation of fund to each of marginally profitable project. Consequently, in asymmetric informational theoretic framework, firms change their strategies in raising their capital. Firms' first best choice for financing their investment in severity of information problem, rests on their internal funds since it is the cheapest and more unrestricted source of finance to the managers. To this milieu, this paper focuses on investigating whether the Nepalese enterprises depend on their internal funds to finance their investment or not? World Bank Enterprise Survey data set are employed to examine the investment and financing policies of Nepalese enterprises. The data set consist of financial information of 968 firms across multiple size, sector and age category. We employ simple measures of descriptive statistics like frequencies, percentage and arithmetic mean viz; the average of a set of numerical values to analyze the data by sorting the observations to various portfolios. The study result confirms that the firms heavily depend on their internal funds to finance their investment. These results are consistent with prior literatures for example; Fazzari, Hubbard, \& Peterson (1988), Gilchrist \& Himmelberg (1995), Hu \& Schiantarelli (1998) etc when observed in cross section of size, sector, age and ownership pattern of enterprises.
\end{abstract}

JEL Classification; E41, G31, G32,

Key Terms: investment decisions, financial policy, capital market imperfection, information asymmetry

\section{Introduction}

In perfect capital market, real activities of enterprises are independent of its financial decisions (Modigliani $\&$ Miller, 1958). Consequently financial policies of the firms or sources of finance have no bearing on their capital investment decisions. In Modigliani- Miller framework of capital market, no firms are constrained by finance if they have profitable investment opportunities. When capital markets are efficient, funds get allocated to every marginal project with profitable opportunities. But assumption of efficient capital market does not work in real world including well developed economies; let depart the cases for developing countries and emerging markets. Contrary to the neo-classical models developed since 1950s, recent theoretical and empirical studies stressed on the relationship between finance and investment (Minsky, 1975; Fazarri, 1994). 
A vast theoretical and empirical literatures following the seminal work of Fazzari, Hubbard \& Peterson (1988) suggest that firms facing information and agency problems are constrained by finance even if they had profitable investment opportunities. When firms face information problems in capital markets, cost of external finance exceeds that of internal funds. In such phenomenon, debt and equity markets are not easily accessible to Small and Medium Enterprises (SMEs) due to procedural and financing constraints. Consequently SMEs operating in underdeveloped financial market depend heavily in their own internal funds and profitability along with support from bank and intermediaries to finance their working capital and fixed assets purchase. The rationale for the relevance of the internal finance could be defended from two theoretical perspectives: The managerial approach emphasizes agency costs arising out of the separation of ownership from control and the role of internal finance in facilitating managerial discretion (Townsend, 1979). However in context of developing countries, the primary agency problem has been between majority and minority owners (not between owners and managers).

The second approach i.e. the information-theoretic approach emphasizes asymmetries of information between insiders (managers) and outsiders (suppliers of capital) leading to credit shortage faced by firms (Stieglitz \& Weiss, 1981). Asymmetric information in investor-firm relationship necessarily creates disruptions in financial markets, leading to inefficient allocation of investible funds (Mishkin, 1996). In this framework, information failures relate to the failures of intermediaries and stock markets and it thus argues for government intervention.

In asymmetric information framework, choices of source of finance by firm follows the pecking order as suggested by Myers. The pecking order hypothesis suggests that firms have a particular preference order for financing choices used to finance the firm (Myers \& Majluf, 1984). In particular, due to the presence of information asymmetries between the firm and the potential financiers, the relative costs of finance will vary between the financing choices. For example, inside finance (retained profits or contributions of existing owners), where the funds provider is the firm itself and it will have more information about the firm than new equity holders, therefore these new equity holders will expect a higher rate of return on capital invested, resulting in new equity finance being more costly to the firm than using existing internal funds (Bernanke \& Gertler, 1995). A similar argument can be provided between inside finance and new debt-holders. Additionally, the greater the exposure to the risk associated with the information asymmetries for the various outside financing alternatives available, the higher the return of capital demanded by each source. Consequently, the firm will prefer inside finance to debt, short-term debt over long-term debt, and any debt over outside equity (Myers \& Majluf, 1984).

Financing choice of firm is affected by different firm specific attributes. One of the most important firm characteristics determining its financing policy is the size of the firm. There are several theoretical reasons why firm size would be related to the financial structure of the firm (Fazzari, Hubbard, \& Peterson, 1988). Firstly, smaller firms may find it relatively more costly to resolve informational asymmetries with lenders and financiers. Consequently, smaller firms are offered less external capital, or are offered capital at significantly 
higher costs than to larger firms, which discourage them to the use of external financing. Size increases the probability that firms face binding financing constraints (Hu \& Schiantarelli, 1998). Their interpretation invokes agency problems associated with the dispersed ownership of large firms' shares that outweighs the fact that these large firms may be older and well known to investors. The transaction costs associated with issue of debt and equity may also affect financing choices as transaction costs are most likely a function of size, with smaller scale financing resulting in relatively higher transaction costs. A related issue is the marginal effects of market access for different sized firms. This could be a function of high transaction costs effectively making some financing options outside the available set of financing choices of the firm. Another explanation for smaller firms having less outside financing or lower debt is the relative costs of bankruptcy are an inverse function of firm size (Gilchrist \& Himmelberg, 1995).

The hypothesized relationship between the age of firm and informational asymmetry is inverse. Typically younger, less well known firms are more vulnerable to capital market imperfection induced by informational asymmetries and collateral requirement (Gilchrist \& Himmelberg, 1995). Given the information asymmetries between the firm and outsiders, firms have a preference for inside financing over outside financing, as the cost for outside capital should be greater for the firm. But cost wedge between external and internal financing decreases as the age of firm increases. The old aged matured firms face less information problem since they develop long-term relationship with bank and financial market. Consequently, younger firms, which have less access to financial markets, depend heavily on internal funds.

Clearly if the information asymmetries are larger for certain firms, the difference in cost of capital for various financing choices should widen and the pecking order preference for the firm becomes more pronounced. The cross sectional properties of firms like age, size, sector, and ownership pattern determine the severity of information and agency problem of particular firm leading them to adopt dissimilar financing policies. Directed to this line of research, few studies suggest that Nepalese enterprises are severely affected by financial constraints (Pradhan \& Kurmi, 2004). With severity of information and agency problem, Nepalese financial market is not efficient enough to transfer funds to profitable investment projects (Subedi, 2008). The study suggest that even large firms do not produce and publish financial reports timely, making the firm's economic activities non transparent and suspicious inside the black box. Hence, investors are found hesitant to invest their money in such an uninformed lemon's market. In such an information asymmetric framework, it is not an overstatement to hypothesize that the small and medium enterprises suffers more heavily than large firms for financing their information based investment. Hence, the present study focuses to examine investment and financing policies of Nepalese enterprises.

Basically the study attempts to resolve the broad issue regarding whether the financing practices of Nepalese firms can be explained by the pecking order framework as suggested by Myers and Majluf (1984), and Myers (1984) in the context of well developed economies. The study attempts to examine whether the firm specific attributes help to explain the choice of financing sources of Nepalese firms to finance their investment in fixed assets. The implication of size, sector, collateral, age and ownership structure of 
enterprises on determining financing decisions of firms are studied by analyzing secondary data collected and published by World Bank.

\section{Data and Methodology}

This study uses the World Bank’s Enterprise Survey Panel Data Set 2009 and 2013 (World Bank, 2013) to analyze the differences in fixed assets financing over the cross-section of Nepalese enterprises. The World Bank's Enterprise Surveys collects data from key manufacturing, retail and service sector in every region of the world. In Nepal, it collected panel data in 2009 and 2013. The sample comprised manufacturing firm, service enterprises, retail and micro firms as presented in table 1.

Table 1 Number of sample enterprises by sector and size

\begin{tabular}{|l|l|l|l|}
\hline \multicolumn{1}{|c|}{ Sector Category } & \multicolumn{1}{|c|}{ No. of firm } & Percent & Cum. \\
\hline Manufacturing firms & & & \\
\hline Retail firms & 378 & 39.05 & 39.05 \\
\hline Service firms & 231 & 23.86 & 62.91 \\
\hline Micro firms & 241 & 24.90 & 87.81 \\
\hline Total & 118 & 12.19 & 100.0 \\
\hline Size Category & $\mathbf{9 6 8}$ & $\mathbf{1 0 0 . 0}$ & \\
\hline No. of Employees & & & \\
\hline Micro (less than 5) & & & \\
\hline Small $(>=5$ and $<=19)$ & 118 & 12.19 & 12.19 \\
\hline Medium $(>=20$ and $<=99)$ & 478 & 49.38 & 61.57 \\
\hline Large $(>=100$ \& above) & 292 & 30.17 & 91.74 \\
\hline & 80 & 8.26 & 100.0 \\
\hline Total & & & \\
\hline
\end{tabular}

The secondary data taken from the survey comprises multiple variables including technology, innovation, labour, finance, business environment etc. But this study uses the information that only deals with financial aspects of the firm. In particular, it examines differences in financing policies by firm size, sector, age, ownership type, and locality of establishment. We investigate these differences by analyzing descriptive statistics like percentages and mean values across firm groups and then discuss the results across the various categories of firms.

\section{Discussion and Results}

\subsection{Firm Financing by Size}

Firm size is one of the most important proxies of information. Theoretical propositions of size variable are negatively related with information asymmetry between borrowers and lenders ( (Levine \& Renelt, 1992) (Bond \& Meghir, 1994)). As the size of firm increases, it reduces the information problem in financial market. Table 2 classifies the firm into four size categories as per the number of permanent workers employed in 
respective firms. The firms with less than 5 permanent employees are categorized as micro enterprises and there are 26 micro enterprises out of total sample. Similarly, 136 enterprises are small enterprises comprising 5 to 10 permanent employees. Medium enterprises are the category with 20 to 99 permanent employees and they represent 116 firms. Out of total sample, 46 enterprises are large firms employing more than 100 permanent employees as per database of Enterprise Survey-2013. It indicates the relative importance of internal sources of funds for financing investment in fixed assets purchase by sample firms.

Tables 2 clearly indicates that the micro and small firms depends heavily on internal funds to finance their investment but the ratio of dependency decreases monotonically when size of the firm increases. Similarly the data base of Enterprise Survey 2009 provides information on fixed assets purchase of 153 enterprises and their relative use of different sources of finance like internal funds, owner's equity, formal bank loan, other non bank institution finance and trade credit finance. The information on micro firms are not available for the year 2009 .

The large firms use relatively higher portion of bank loan as compared to other category of firms for financing their investment. These observations are even more prominent in the year 2009, which shows that the ratio of formal bank finances in large firms are substantially higher than small enterprises. The table 2 also explores the extent of access to bank financing by firms under the midst of expansion of financial intermediaries and financial market liberalization in Nepal.

Table 2 Relative sources of fixed assets financing by firm size (Mean Ratio in \%)

\begin{tabular}{|c|c|c|c|c|c|c|c|c|c|c|c|}
\hline \multirow{2}{*}{$\begin{array}{l}\text { Firm size } \\
\text { Size/ Year }\end{array}$} & & \multicolumn{2}{|c|}{$\begin{array}{l}\text { Internal } \\
\text { funds }\end{array}$} & \multicolumn{2}{|c|}{$\begin{array}{l}\text { Owner's } \\
\text { Equity }\end{array}$} & \multicolumn{2}{|c|}{$\begin{array}{c}\text { Bank } \\
\text { finance }\end{array}$} & \multicolumn{2}{|c|}{$\begin{array}{l}\text { Non-bank } \\
\text { finance }\end{array}$} & \multicolumn{2}{|c|}{$\begin{array}{c}\text { Trade } \\
\text { creditors }\end{array}$} \\
\hline & & 2013 & 2009 & 2013 & 2009 & 2013 & 2009 & 2013 & 2009 & 2013 & 2009 \\
\hline \multirow{2}{*}{$\begin{array}{l}\text { Micro firms } \\
\text { (less than 5) }\end{array}$} & $\%$ & 76.15 & - & 4.61 & - & 1.92 & - & 13.46 & - & 0 & - \\
\hline & $\mathbf{N}$ & 26 & - & 26 & - & 26 & - & 26 & - & 26 & - \\
\hline \multirow{2}{*}{$\begin{array}{l}\text { Small firms } \\
(>=5 \&<=19)\end{array}$} & $\%$ & 75.19 & 81.39 & 8.27 & 5.32 & 9.139 & 8.77 & 5.25 & 2.86 & 1.02 & 0.81 \\
\hline & $\mathbf{N}$ & 136 & 61 & 136 & 61 & 136 & 61 & 136 & 61 & 136 & 61 \\
\hline \multirow{2}{*}{$\begin{array}{l}\text { Medium firms } \\
(>=20 \&<=99)\end{array}$} & $\%$ & 70.00 & 75.15 & 5.78 & 1.30 & 21.99 & 20.87 & 0.43 & 0.72 & 0.52 & 0.12 \\
\hline & $\mathbf{N}$ & 116 & 70 & 116 & 70 & 116 & 70 & 116 & 70 & 115 & 70 \\
\hline \multirow{2}{*}{$\begin{array}{l}\text { Large firms } \\
(>=100 \& \text { above) }\end{array}$} & $\%$ & 64.45 & 58.86 & 5.43 & 11.3 & 27.93 & 29.77 & 0 & 1.48 & 0 & 0.26 \\
\hline & $\mathbf{N}$ & 46 & 22 & 46 & 22 & 46 & 22 & 46 & 22 & 46 & 22 \\
\hline \multirow[t]{2}{*}{ Total } & $\%$ & 71.89 & 75.30 & 6.68 & 4.35 & 15.83 & 17.32 & 3.44 & 1.47 & 0.62 & 1.18 \\
\hline & $\mathbf{N}$ & 324 & 153 & 324 & 153 & 324 & 153 & 324 & 153 & 323 & 153 \\
\hline
\end{tabular}

Despite the intensity of financial market liberalization and banking sector growth in Nepal, micro and small firms still have very little access to formal bank lending to finance their growth and expansion. Resembling the theoretical financing frictions like asymmetric information and moral hazards in imperfect capital market as postulated by FHP (1988), the small and micro enterprises in Nepal are restricted by formal banking 
channels and they rely heavily on retained earnings and other informal channels like non-bank financing and money lenders that charges relatively higher interest rates with less debt maturity period. These firms' over reliance on internal funds to fixed assets financing signals the severity of information and agency problems in Nepalese capital markets. The hierarchy of financing in Nepalese firms is also noticed from the table 2. The first best choice of finance for Nepalese firms is internal funds (71.89\%), bank financing (15.83\%) is the second most important source of funds and the owner's contribution or equity $(6.68 \%)$ constitutes the last resort supporting the pecking order hypothesis as suggested by Myers and Majluf (1984).

\subsection{Firm's Fixed Assets Financing Ratios by Age}

Firms were split on their age -calculated as the number of years since the date of incorporation -into three categories: firms that are less than six years old, firms between 6 to 11 years old and firms over 11 years old. The results from comparing mean financing ratios by age categories are presented in table 3 . It indicates that older firms (those over 11 years old) employed more banks financing to invest in fixed assets than younger firms. Level of bank financing increase steadily along with increase in firm's age. The difference is noticed significant - as firms that are less than 6 years old, they finance about $10.36 \%$ of their investment with formal bank financing, those older than 11 years finance $12.26 \%$ of their assets with formal bank lending, further this trend increases to $18.37 \%$ in case of older firms which is about a $80 \%$ increase in the ratio.

Table 3 Fixed assets financing ratio by firm's age

\begin{tabular}{|c|c|c|c|c|c|c|c|}
\hline $\begin{array}{c}\text { Age } \\
\text { ( in year) }\end{array}$ & Statistics & $\begin{array}{c}\text { Internal } \\
\text { funds }\end{array}$ & $\begin{array}{c}\text { Owners } \\
\text { equity }\end{array}$ & $\begin{array}{c}\text { Bank } \\
\text { finance }\end{array}$ & $\begin{array}{c}\text { Non-bank } \\
\text { finance }\end{array}$ & $\begin{array}{c}\text { Trade } \\
\text { creditors }\end{array}$ & Other \\
\hline \multirow{2}{*}{$\begin{array}{l}\text { Below } 6 \\
\text { years }\end{array}$} & Mean (\%) & 65.27 & 7.18 & 10.36 & 10.81 & 2.18 & 4.18 \\
\hline & $\mathrm{N}$ & 55 & 55 & 55 & 55 & 55 & 55 \\
\hline \multirow{2}{*}{$\begin{array}{l}7 \text { to } 11 \\
\text { years }\end{array}$} & Mean (\%) & 76.93 & 7.30 & 12.26 & 2.38 & 1.11 & 0 \\
\hline & $\mathrm{N}$ & 63 & 63 & 63 & 63 & 63 & 63 \\
\hline \multirow{2}{*}{$\begin{array}{l}12 \text { years } \\
\& \text { above }\end{array}$} & Mean $(\%)$ & 72.11 & 6.36 & 18.37 & 1.80 & .053 & .097 \\
\hline & $\mathrm{N}$ & 206 & 206 & 206 & 206 & 205 & 205 \\
\hline
\end{tabular}

A reverse pattern is observed in the ratio of non-bank finance to fixed assets purchase. Younger firms rely more on non-bank finance and other informal sources like money lenders, relatives etc to finance their fixed assets purchase. It was found that younger firms borrow more from other sources (more likely from cooperatives, micro finance, relatives and money lenders) than older firms do, while older firms borrow more from formal bank and financial institutions. This pattern, combined with the above results on debt to assets ratios, is indicative of the possibility that younger firms have more difficulty accessing credit from formal financial intermediaries and, therefore, resort to credit from other sources, which take on a role of 
informal credit providers. The results support the various studies in well developed economies including Bond and Meghir (1994), Rajan and Zingale (1995) etc.

\subsection{Firm Financing Pattern by Sector}

Sample firms have been classified into three broad industrial groups viz- manufacturing, retail and services excluding the micro enterprises from each of the category. It was found that average manufacturing firms have more use of formal bank financing than service firms as indicated in table 4. It is found a similar, although less pronounced pattern for internal funds to new assets purchase among sample enterprises. However, service enterprises rely more on internal funds (78.61\%) to assets purchase than other firms.

Table 4 Relative sources of fixed assets financing by sector

\begin{tabular}{|c|c|c|c|c|c|c|c|}
\hline Sector & Statistics & $\begin{array}{l}\text { Internal } \\
\text { funds }\end{array}$ & Equity & $\begin{array}{c}\text { Bank } \\
\text { finance }\end{array}$ & $\begin{array}{c}\text { Non-bank } \\
\text { finance }\end{array}$ & $\begin{array}{c}\text { Trade } \\
\text { creditors }\end{array}$ & Other \\
\hline \multirow[t]{2}{*}{$\begin{array}{l}\text { Manufacturing } \\
\text { firms }\end{array}$} & $\begin{array}{l}\text { Mean } \\
(\%)\end{array}$ & 67.08 & 8.27 & 21.61 & 1.43 & 0.64 & 0.21 \\
\hline & $\mathbf{N}$ & 139 & 139 & 139 & 139 & 139 & 139 \\
\hline \multirow[t]{2}{*}{ Retail Firm } & $\begin{array}{l}\text { Mean } \\
(\%)\end{array}$ & 68.16 & 4.48 & 14.89 & 7.55 & 2.44 & 2.4 \\
\hline & $\mathbf{N}$ & 49 & 49 & 49 & 49 & 49 & 49 \\
\hline \multirow[t]{2}{*}{ Service Firm } & $\begin{array}{l}\text { Mean } \\
(\%)\end{array}$ & 78.61 & 6.14 & 12.21 & 1.78 & .081 & 0 \\
\hline & $\mathbf{N}$ & 110 & 110 & 110 & 110 & 110 & 109 \\
\hline \multirow[t]{2}{*}{ Total } & $\begin{array}{l}\text { Mean } \\
(\%)\end{array}$ & 71.52 & 6.86 & 17.04 & 2.57 & 0.67 & 0.50 \\
\hline & $\mathbf{N}$ & 298 & 298 & 298 & 298 & 298 & 297 \\
\hline
\end{tabular}

In terms of the composition of borrowing sources, table 4 indicates that manufacturing firms use slightly more bank debt (21.61\%) than retail firms (14.39\%) and service firms (12.21\%). Retail firms borrow more from other non banking sources and less from financial institutions, which could be indicative of their weaker access to intermediated finance. Service firms use less bank loan, probably because they have less fixed assets that could be used as collateral. This could also explain their weaker access to intermediated finance and their overall levels of debt.

Breaking down industrial groups into finer sector groupings, it is noticed that among manufacturing firms, those in machinery and equipment, the Plastic and Rubbers, Publishing \& Printing and Fabricated Metal sectors use more bank finance i.e. $45 \%, 34 \%, 32 \%$ and $25.4 \%$ respectively. There is no large difference in access to trade credit. 


\subsection{Fixed Assets Financing by Ownership Type}

The enterprises are separated into three categories by their ownership type on the basis of legal status viz; Shareholding Company, Sole proprietorship and Partnership. Relatively Shareholding Company and partnership firm use more debt financing as seen in table 5. The ratio of equity finance is highest in partnership firm. However there is no noticed pattern of use of trade credit finance and other informal sources among the firms with different legal status and ownership type.

Table 5 Fixed assets financing ratio by ownership type

\begin{tabular}{|l|l|l|l|l|l|l|l|}
\hline \multicolumn{1}{|c}{ Legal status of firm } & Stat. & $\begin{array}{c}\text { Internal } \\
\text { funds }\end{array}$ & Equity & $\begin{array}{c}\text { Bank } \\
\text { finance }\end{array}$ & $\begin{array}{c}\text { Non-bank } \\
\text { finance }\end{array}$ & $\begin{array}{c}\text { Trade } \\
\text { creditors }\end{array}$ & Other \\
\hline Shareholding Company & $\%$ & 70.7 & 6.46 & 18.1 & 2.75 & 1.11 & 0.37 \\
\hline & $\mathrm{N}$ & 189 & 189 & 189 & 189 & 189 & 189 \\
\hline \multirow{2}{*}{ Sole proprietorship firm } & $\%$ & & & & & & \\
\hline & $\mathrm{N}$ & 115.8 & 6.35 & 12.3 & 5.04 & 0 & 1.57 \\
\hline & & & & & & & 115 \\
\hline Partnership firm & $\%$ & 62.7 & 115 & 20.7 & 1.67 & 0 & 0 \\
\hline & $\mathrm{N}$ & 15 & 15 & 15 & 15 & 15 & 15 \\
\hline \multirow{2}{*}{ Total } & & & & & & & \\
\hline & $\%$ & 72.1 & 6.73 & 15.9 & 3.48 & 0.65 & 0.74 \\
\hline & $\mathrm{N}$ & 319 & 319 & 319 & 319 & 319 & 319 \\
\hline
\end{tabular}

The sole proprietorship uses more internal fund in comparison of other enterprise. These enterprises still depend upon informal institutions and other sources like money lenders, relatives etc to finance their fixed assets purchase. This could be because they suffer from severity of information problem since they have no legal requirement to disclose their operation and financial statements to outsiders.

\section{Conclusion}

Using a World Bank Enterprise Survey data comprising a set of firms surveyed in 2009 and 2013, present study addressed a set of research questions focusing on business fixed investment and their financing policies. Firstly, it observed the presence of capital market imperfections through the analysis of relationship between firm investment and internal finance. In addition, it investigated the possibility that this relationship varies across firms of different size, age, sector and ownership pattern. Study findings confirm the imperfection of the Nepalese capital market and highlight the differential impact of financing constraints across young and smaller firms. Firm specific age and size attributes do appear to be useful proxies for the degree of asymmetric information and consequently can be used in order to assess financing constraints. The study findings support the financing constraints hypothesis explaining real activities of the firms facing informational asymmetry problems in imperfect capital markets as suggested by Fazzari, Hubbard and Peterson (1988), Hu and Schiantarelli (1998) and (Subedi, 2008) among others. 


\section{References}

Bernanke, B., \& Gertler, M. (1995). Inside the Balck Box: The Credit Channel of Monetary Policy Transmission. Journal of Economics Perspectives, 27-48.

Bond, S., \& Meghir, C. (1994). Dynamic investment model and firm's financial policy. The Review of Economic Studies, 197-222.

Fazzari, S., Hubbard, G., \& Peterson. (1988). Financing Constraints and Corporate Investment. Brooking Papers on Economic Activity .

Gilchrist, S., \& Himmelberg, C. (1995). Evidence on the Role of Cashflow for Investment. Journal of Monetary Economics, 541-572.

Hu, X., \& Schiantarelli, F. (1998). Investment and Capital Market Imperfections; A Switching Regression Approach Using US Firm Panel Data. The Review of Economics and Statistics, 466-479.

Levine, R., \& Renelt, D. (1992). A Sensitivity Analysis of Cross Country Growth Regression. The American Economic Review, 942-963.

Minsky, H. P. (1975). John Maynard Keynes. Columbia University Press.

Mishkin, F. S. (1996, February). The Monetary Transmission Mechanism: Lessons for Policy. Mimeo .

Modigliani, F., \& Miller, M. (1958). The Cost of Capital, Coproration Finance and Theory of Capital Structure. The American Economic Review , 261-297.

Myers, S. C., \& Majluf, N. S. (1984). Corporate Financing and Investment Decisions When Firms Have Information That Investors Do Not Have. Journal of Financial Economics, 187-221.

Pradhan, R. S., \& Kurmi, M. P. (2004). A Relationship Between Firm Investment and Financial Status of Nepalese Enterprises. Journal of Management and Development Review , 9-16.

Stieglitz, E., \& Weiss, A. (1981). Creidt Rationing in Market with imperfect information. American Economic Review, 393-410.

Subedi, K. D. (2008). Corporate Investment and Financing Constraints; The Nepalese Evidences. Kathmandu: An Unpublished M.Phil Dissertation,Faculty of Management, TU.

Subedi, K.D.(2012). A Survey on Corporate Investment Practices in Nepal. Saheedsmriti Journal, 1-16

Subedi, K.D. (2014). Corporate Investment and Financing Constraints; Nepalese Evidences. The Sapatagandaki Journal, 28-35.

Townsend, R. M. (1979). Optimal Contracts and Competitive markets with Costly State Verification. Journal of Economic Theory, 265-93.

World Bank. (2013). Business Environment In Nepal. Retrieved from www.enterprisesurveys.org. 